\title{
Research into Cyberbullying: Student Perspectives on Cybersafe Learning Environments
}

\author{
Elizabeth STACEY \\ Deakin University \\ 221 Burwood Highway Burwood, Victoria, Australia 3125 \\ e-mail: estacey@deakin.edu.au
}

Received: June 2008

\begin{abstract}
This paper reports a qualitative study designed to investigate the issues of cybersafety and cyberbullying and report how students are coping with them. Through discussion with 74 students, aged from 10 to 17, in focus groups divided into three age levels, data were gathered in three schools in Victoria, Australia, where few such studies had been set. Social networking sites and synchronous chat sites were found to be the places where cyberbullying most commonly occurred, with email and texting on mobile phones also used for bullying. Grades 8 and 9 most often reported cyberbullying and also reported behaviours and internet contacts that were cybersafety risks. Most groups preferred to handle these issues themselves or with their friends rather then alert parents and teachers who may limit their technology access. They supported education about these issues for both adults and school students and favoured a structured mediation group of their peers to counsel and advise victims.
\end{abstract}

Keywords: cyberworld, cybersafety, cyberbullying, Internet, social networking, synchronous chat, texting, mobile phones.

\section{Introduction}

School students today have access to a new connected cyberworld through the Internet and through their use of many information and communication technologies (ICT) including computers and mobile phones. There are few Australian studies that provide details of this cyberworld and these are often anecdotal, with the issues that are arising for students to manage in this world often new and ascribed with the fear of the unknown by many teachers and parents. Strategies and advice for managing the personal, ethical and privacy impacts and intrusions that students are facing daily can only be developed through a researched understanding of their cyberworld. The advent of social networking sites such as MySpace and Facebook and the widening use of synchronous chat sites such as MSN in Australia are adding landscapes to this cyberworld that are even less familiar to parents and teachers and have become the online playground for cyberbullying that can continue after school hours and intrude into victims' previously safe home environments. 


\section{Review of Literature}

Reports of research have explored relatively small and localised populations of young people internationally. Several Canadian studies have begun to identify communication usage of Canadian youth (Steves, 2005) and a well designed research project that surveyed electronic bullying in rural Ontario (Stys, 2004) described a distinct form of bullying, unlike traditional playground bullying, that involved as many female as male participants, whether bullies, victims or onlookers. This could have a stronger impact on the victims due to the intrusiveness of the bullying outside of school hours and the potential widespread dissemination of some forms of electronic bullying. Stys' study surveyed a population of 232 students but identified a missing qualitative aspect that would help interpretation of the survey results. Another Canadian researcher, Li (2005), surveyed 177 grade 7 students, $54 \%$ of whom reported being cyberbullied . Li $(2006,2007)$ has followed this research with other survey-based studies, one ( $\mathrm{Li}, 2006)$ which found that boys claimed a higher incidence of bullying both in person and electronically and another (Li, 2007), a comparative study of Chinese and Canadian 7th grade students. In this study she found that one third of the whole cohort had been cyberbulied and over a half knew someone who had been cyberbullied with a higher proportion of males either bullying or victims of cyberbullying. The Canadian cohort were four times more likely to cyberbully than the Chinese students with more Chinese students claiming to be cybervictims than the Canadian students. $\mathrm{Li}$ (2007) found that those who bullied also cyberbullied and "gender was a significant predictor of cyberbullying" (p. 449) with males most commonly both bullies and cyberbullies and students expressing little faith in reporting to adults which she interpreted as possibly because they thought adults would not act on their reports. Both her reasons for why males were more likely to be cyberbullies than females, and why students wouldn't report cyberbullying to adults had no qualitative data to provide further explanation and relied on her interpretation only .

A UK study of 92 participants (Smith et al., 2006) found that cyberbullying was becoming more prevalent, with phone and text messages and email the most common forms of cyberbullying. Kowalski and Limber (2007) identified a need for a US study of cyberbullying which they carried out by survey in six elementary and middle schools (grades 6, 7 and 8) in southwestern and northwestern United States. Along with high internet and mobile phone usage they found that more female students (25\%) than males had been cyberbullied in the previous 2 months and that younger students reported less bullying. They suggested that the anonymity of the bullies could be harmful to students who could later suspect each person they met of being the bully. As with other studies, the students were reluctant to report cyberbullying to parents as this may result in their restricting their electronic communication.

So far within Australia, Campbell (2005) has investigated the impact of mobile phones on young Australians and has reviewed the problem of cyberbullying from the international research literature. She cites traditional definitions of bullying as "aggressive behaviour that is repeated over time, is intentionally harmful and occurs without provocation" (citing Peterson, 2001, p. 2). Campbell describes methods of cyberbullying as 
including texting derogatory messages, often sharing these more widely, sending threatening emails or forwarding emails to a wider audience and humiliating the sender and using derogatory web sites to defame victims by description or photo. She reports texting, chat rooms and email as most commonly used to cyberbully in UK and Australian studies and cited Blair's (2003) study indicating girls were more likely to use such covert methods of bullying than males and reported that parents were perceived as unaware of their students cyberworlds.

Bamford (2004) and Carr-Greg (2007) have developed advice and strategies for handling cyberbybullying from reviewing research and practice, but little Australian data on the area has been published so far to provide understanding and support for the most effective strategies for dealing with such issues. A phone survey of 502 homes (children and parents) about Internet usage and safety issues (NetRatings Australia, 2005) has provided useful data but did not investigate bullying, Studies have indicated that almost half of students who were bullied using technology told nobody, for fear of having their computers or mobile phones taken away from them, creating further isolation (Patchin and Hinduja, 2006).

Though studies link cyberbullying to research findings and definitions of traditional face to face bullying (Li, 2006, 2007; Campbell, 2005; Kowalski and Limber, 2007), and have accepted these as a definitional base for cyberbullying, this may be found to change in the new environment of the cyberworld where intention may be hard to estimate and one dissemination of a humiliating photo or message may occur only once but bring repetitive responses that act like repeated acts of bullying. Wolak et al. (2007) discussed the definitional differences between online harassment and bullying and suggested that cyberbullying involved "a series of incidents by the same harasser (indicating repetition) and either distressing (possibly indicating aggression and imbalance of power) or requiring adult intervention" (pS56). The student perspective and their definitional understandings of what constitutes cyberbullying and the impact of such incidents, particularly from an Australian perspective, was lacking in the studies reviewed. Consequently the qualitative study described below was designed to investigate an Australian school context from a student perspective.

\section{Research Study}

This qualitative study researched three schools in representative localities and age groups with the specific focus of investigating student internet and communication technology usage and student experience of cybersafety and cyberbullying issues in Australian settings. All three schools were independent (church affiliated) schools which, though not fully representative of the general population with students more typically from higher socio-economic backgrounds, ensured that the sample would have participants who had the means to access personal computers and internet communication and with a higher possibility of mobile phone ownership who would be able to comment on the issues under investigation. 
The research project was developed to explore the research question:

- What is the cyberworld with which Australian school students are coping? with sub-questions of:

- What technologies do they use and how do they use them?

- What impact and issues do they face, particularly in relation to cyberbullying?

- What is and should be their community's response to the issues they report?

\section{Data Collection}

Qualitative data were collected by:

1) Student discussion

At each of the three schools three focus groups of internet users were set up by grade/age each with up to 10 students at grade levels of:

- younger (grades 5-7, 10-13 years old),

- middle (grades 8-9,13-15 years old) and

- older (grade 11, 16-17 years old).

These schools were regionally and school type representative with:

i) 1 girls-only city school,

ii) 1 regional co-educational boarding school and

iii) 1 rural co-educational day school.

There were a total of 9 discussion groups of 74 participants who met for 30 minutes or more to discuss a range of starter questions (see Table 1). All but one of these discussions was audio recorded for analysis with the one audio recording interruption supplemented by detailed field notes taken by the researcher.

2) Student surveys

As groups assembled for focus group discussions they were asked to complete a one page survey of demographic and usage information. They were asked where they used

Table 1

Discussion group starter questions

When you are online what do you spend your time doing?

Have any of you been cyberbullied (after defining/discussing term)?

If so by what means - email, chat, MySpace etc?

Have you heard rumours/gossip about cyberbullying happening in your school?

Have you witnessed or heard about such cyberbullying?

Please tell me about any difficult experiences online - what happened? How did you feel? What did you do about it?

What would make it easier to tell someone about cyber bullying?

Please tell me your thoughts on cyber bullying and your ideas for stopping or preventing it. What can kids do to protect themselves from cyber bullying?

Have you ever considered meeting with someone whom you had only talked to online?

Have you met with someone whom you had only talked to online?

Do parents and teachers understand what you do on the internet? Is it their business? 
their computers and to calculate how many hours they spent online and in mobile phone usage in an average day with a breakdown to an estimate of hours spent on instant messaging, social networking sites, email, mobile phone texting or any other online communication.

\section{Data Analysis}

1) Student Discussions

The main points of discussion were noted from the audio recordings and field notes. These notes were used to draw up summary tables, which identified relevant information in answer to four questions:

- What do students mainly do online?

- What kinds of negative activities are evident?

- How do students and schools respond?

- What else could be done?

The tables were then sorted into age groups and examined: there were three groups of students aged 10-13; three groups of students aged 13-15 and three groups of students aged 16-17. The main points from each age group were summarised and noted under the four questions listed above. The similarities and differences between age groups were identified and the data were also examined for differences according to locality.

2) Student surveys

There were 74 survey returns identifying demographic and usage information. Tables were created to show differences in student use of the Internet/mobile technologies between the age groups in each of the three localities as well as comparisons of each age group. The quantitative data were used to work out patterns of usage between the different technologies and the different age groups and localities and to compare and support the discussion data about technology usage and experience.

\section{Findings}

Overall, the findings showed that the Internet is used everywhere and by everyone every day while mobile phone usage is widespread from age 13 onward (see summary of usage, Table 2). Despite advice to parents about supervision for cybersafety, most secondary school students used computers in bedrooms or, in some cases, in rooms such as studies, where students are online alone. Online social networking was becoming more widely used as the students progressed through secondary school, with MySpace popular for day students in years 7 to 9 while Facebook was beginning to be used in older school grades. The findings are discussed first as a comparison of usage and experience within each of the three age groups and then with a discussion of the influence of the different school contexts on these groups. 
Table 2

Summary of all schools' technology and online use

\begin{tabular}{|c|c|c|}
\hline School 1: city-girls only & $\begin{array}{l}\text { School 2: regional co-ed } \\
\text { boarding school }\end{array}$ & School 3: rural co-ed \\
\hline $\begin{array}{l}\text { Everyone had a mobile phone and } \\
\text { sent text messages every day }\end{array}$ & $\begin{array}{l}\text { About half of the younger stu- } \\
\text { dents had mobile phones but al- } \\
\text { most all the older students had } \\
\text { one Text messaging common } \\
\text { though not at a high rate }\end{array}$ & $\begin{array}{l}\text { Almost everyone had a mobile } \\
\text { phone and text messaging was } \\
\text { common though only high among } \\
\text { girls in grade } 9\end{array}$ \\
\hline $\begin{array}{l}\text { Everyone spent time on the Inter- } \\
\text { net each day }\end{array}$ & $\begin{array}{l}\text { Everyone spent time on the In- } \\
\text { ternet each day }\end{array}$ & $\begin{array}{l}\text { Everyone spent time on the Inter- } \\
\text { net each day }\end{array}$ \\
\hline $\begin{array}{l}\text { All 9th graders were on MSN chat } \\
\text { each day but only } 50 \% \text { of grade } 7 \\
\text { and } 11 \text { students }\end{array}$ & $\begin{array}{l}\text { MSN chat was not used exten- } \\
\text { sively particularly as boarders } \\
\text { were restricted to email and web } \\
\text { browsing }\end{array}$ & $\begin{array}{l}\text { Many senior students refrained } \\
\text { from MSN as too time consum- } \\
\text { ing, distracting from study but } \\
\text { most of the younger students were } \\
\text { active }\end{array}$ \\
\hline $\begin{array}{l}\text { Blogs and own websites were not } \\
\text { popular at all }\end{array}$ & $\begin{array}{l}\text { Blogs and own websites were } \\
\text { not popular at all. }\end{array}$ & $\begin{array}{l}\text { Chat rooms, blogs and websites } \\
\text { were not popular. }\end{array}$ \\
\hline Email had comparatively little use & $\begin{array}{l}\text { Email was used more exten- } \\
\text { sively than at other locations as } \\
\text { this was the approved form of } \\
\text { electronic communication in the } \\
\text { boarding school }\end{array}$ & $\begin{array}{l}\text { Older students spent time using } \\
\text { email but younger ones hardly } \\
\text { used it at all }\end{array}$ \\
\hline $\begin{array}{l}\text { Almost everyone used MySpace } \\
\text { or Facebook (older students). }\end{array}$ & $\begin{array}{l}\text { Social networking sites were } \\
\text { banned for boarders. }\end{array}$ & $\begin{array}{l}\text { Many senior students refrained } \\
\text { from social networking but most } \\
\text { of the younger students were ac- } \\
\text { tive }\end{array}$ \\
\hline
\end{tabular}

Younger Grades 5-7 (10-13 years old)

There was a variety of activity online in the younger group, mainly after school hours, with games, music, mobile phone texting, browsing the Internet and social networking for day students and restricted access for boarding school students who mainly used email and web browsing. The youngest members of this age group used computers in living areas with bedroom placement of computers less common (40\%) and with the lowest usage of computers ( $70 \%$ for one hour or less a day, $30 \%$ up to 2 hours). By 7 th grade the students were more commonly using computers in their bedrooms $(70 \%)$ or in a study or office placement. The city-based school group spent longer online with $78 \%$ online 1-3 hours daily and the others reporting 5-7 hours of use in a day. The rural based group spent less time online, $70 \%$ under an hour and all under 2 hours a day.

All students played games and communicated online, mainly through email in the youngest group and were beginning to use chat (MSN) and social networking sites like MySpace. Some had also tried other sites such as Bebo but very few were spending long in these sites usually from 30 minutes to an hour and only two of the grade 5/6 group 
using these. Instant messaging was just beginning to be used by $50 \%$ of the participants for 30 minutes to at most 1 hour a day, with a similar amount of time spent on email by most students.

All city-based girls at School 1 had mobile phones with $70 \%$ of the rurally based 7 th graders owning phones while the grade 5/6 group had 50\% ownership. Text messages were sent at a low rate of under 5 messages a day with only 3 students sending 10-15 messages.

The younger age group described a range of negative activities they had experienced or heard of from peers, particularly on MySpace where outsiders intruded (including hackers who sent out messages or inappropriate photos to contacts) and other students from their school circulated misinformation and/or damaging or humiliating comments and posted offensive messages and materials on their MySpace sites for others to see them (Table 3 summary). Harassment by older males had occurred to grade 7 students in both city and rural schools through MySpace as this seems to be the age they are more willing to give access to a stranger either voluntarily or accidentally through their other MySpace contacts. They also described identity theft on email accounts for the purpose of sending nasty messages to others. The youngest group in grade $5 / 6$ were affected by chain emails that threatened death if they weren't sent on to others. Though they had been advised of cybersafety strategies and knew they should delete these messages, there were some students very worried about the reality of this threat. Even the youngest students who had a lower mobile phone ownership were still experiencing harassing text messages and inappropriate sexual messages they found worrying as did the 7 th graders who also described such experiences.

A wide range of cybersafety strategies were suggested, from dealing with the problem alone, to talking about it with friends, siblings, parents and teachers. Simple remedies such as 'deleting' a person were used, where appropriate (e.g., if students do not know the person), but personal confrontation was well regarded in cases where students were harassed by someone they knew. The youngest students saw teacher intervention as a

Table 3

Summary of negative cyber experiences of Grades 5-7 (10-13 years)

\begin{tabular}{|c|c|c|}
\hline $\begin{array}{c}\text { School 1: city-girls only } \\
\text { Grade } 7\end{array}$ & $\begin{array}{c}\text { School 2: regional co-ed } \\
\text { boarding school } \\
\text { Grade } 5 / 6\end{array}$ & $\begin{array}{c}\text { School 3: rural co-ed } \\
\text { Grade } 7\end{array}$ \\
\hline $\begin{array}{l}\text { Outsiders intruding In MySpace } \\
\text { sites (including hackers) }\end{array}$ & Chain mail; junk mail & Hackers \\
\hline $\begin{array}{l}\text { Posting of offensive remarks } \\
\text { where people can see them }\end{array}$ & Intrusive advertising & Stolen identity \\
\hline Fighting & $\begin{array}{l}\text { Sites that prompt for personal de- } \\
\text { tails /cannot exit }\end{array}$ & Intruders or "lurkers" \\
\hline $\begin{array}{l}\text { Harassment of girls by boys/men } \\
\text { - online }\end{array}$ & $\begin{array}{l}\text { MSN messages that spread false } \\
\text { information }\end{array}$ & Spreading nasty stories \\
\hline Text message bulllying & Harassing text message & Harassing text messages \\
\hline
\end{tabular}


solution but many of these grades preferred development of a mediating peer group to help eliminate cyberbullying and also sought technological solutions such as blocking chain email and tracing bullies online. The girls at the city school were particularly not willing to turn to parents and teachers. All considered education about best Internet usage for both students and parents could be helpful.

\section{Middle Grades 8-9 (13-15 years)}

All students in this group were online each day though the rurally based students were online the least (up to only one hour) while the city based group were online the most at least 2 hours (80\%) to 4 hours. The grade 8 students at school 2 reported a wider spread of use from 30 minutes to 6 hours a day though $56 \%$ were only online for up to 2 hours. Most students used their computers in their bedrooms or in a quiet room like a study with some use in family living spaces as well.

Boys still like to play games but, in group discussion, girls reported more interest in inter-personal communication. Instant messaging (MSN) was used by all but one student, usually for up to 1 hour a day and use of MySpace is widespread with all of the city school based grade 9 girls on MySpace for at least an hour a day as were the rurally based girls though the two rural boys in the small sample did not use it. The grade 8 students were starting to explore a wider range of social networking sites from (5) to Facebook (3), Bebo (1) and Teenspot (1) though only three of them were on these sites for up to an hour or more with the restrictions for boarding school students reducing wider use.

Most owned mobile phones, 22 of the 24 students, including all of the girls in the sample, owned their own phones. Differences in the rate of texting may well reflect parental or school restrictions with a small minority claiming high usage from 25 messages up to two to three hundred (3) while most students would send between one and ten messages a day.

Table 4 summarises the negative issues being dealt with by this age group. This group were particularly affected by cyberbullying incidents, from individual incidents to groups

Table 4

Summary of negative cyber experiences of Grades 8-9 (13-15 years)

\begin{tabular}{|c|c|c|}
\hline $\begin{array}{c}\text { School 1: city-girls only } \\
\text { Grade } 9\end{array}$ & $\begin{array}{l}\text { School 2: regional co-ed } \\
\text { boarding school Grade } 8\end{array}$ & $\begin{array}{l}\text { School 3: rural co-ed } \\
\text { Grade } 9\end{array}$ \\
\hline 'Gang' activity & $\begin{array}{l}\text { Emails from strangers asking for a } \\
\text { meeting }\end{array}$ & $\begin{array}{l}\text { Online fighting between (female) } \\
\text { individuals }\end{array}$ \\
\hline Nasty postings on bulletin boards & $\begin{array}{l}\text { People assuming a false identity; } \\
\text { identity 'stolen' }\end{array}$ & Indiscreet use of photos \\
\hline $\begin{array}{l}\text { Circulation of embarrassing pho- } \\
\text { tos/videos }\end{array}$ & Serious threats eg & Awareness of online strangers \\
\hline \multirow[t]{3}{*}{$\begin{array}{l}\text { Interfering with another person's } \\
\text { MySpace site }\end{array}$} & $\begin{array}{l}\text { People finding your personal details } \\
\text { inconspicuously } \\
\text { Loss of privacy }\end{array}$ & $\begin{array}{l}\text { A friend misusing information en- } \\
\text { trusted to them (password) }\end{array}$ \\
\hline & Illicit actions with Internet banking & \\
\hline & Text/email harassment & \\
\hline
\end{tabular}


excluding and ranking others on MySpace sites. External threats to their safety were apparent amongst these students who seemed willing to act riskily with online strangers despite being aware of their potential danger. Identity theft from both persons known to them and externally had been experienced.

This age group preferred to deal with problems themselves. They seemed to feel relatively confident about doing so and would get the help of friends, if needed. Peer support of some kind was also well regarded (especially discussion with older students). Many students in this age group were distrustful of parents and teachers who often do not seem to understand their cyberworld and were perceived to make problems worse. Boarders at School 2 did not seem to have the same level of criticism of their boarding house teachers. It was also noticeable in discussion at school 2 that the group was not especially interested in finding people who had done something wrong and having them punished, according to some code of behaviour. They seemed more interested in ways of evading trouble caused by Internet or phone use, and in avoiding fuss. They appeared to be comfortable in an imperfect cyberworld. The group seemed not to be interested in a higher level of 'defence' against the cyberworld and did not seem to regard the school as having duty of care to 'protect' them.

Students varied, individually, in the level of support they wanted, from whatever source. Some already had that support from parents and older siblings or older students. Better education about the Internet was the only thing all student groups agreed as valuable. They were not looking for better 'policing' and punishment of offenders even describing bans and restrictions of use as challenges that encouraged them to break the rules.

Older Grade 11 (16-17 years)

The older age group used the Internet for more serious pursuits as well as for communicating and socialising: this included discussion of issues with other students (I-earn) and research for school assignments. Placement of computers reflected this more serious intent with most computers placed in bedrooms or studies though rural school 3 still had computers also placed in family living spaces.

All students used the internet daily most often from up to 1-2 hours though one student spent 4 hours online. All except one rurally based student had mobile phones but were not high users of texting with most sending one or two and less than seven and only one female student sending 55 messages.

The majority agreed that communication was their top use of the internet though two girls enjoyed eBay and music downloading was widely used. At schools 1 and 2 students were moving from MySpace ( 8 of 15) to Facebook (7 of 15), while the rurally based group made little use of social networking sites with only one using MySpace for 30 minutes daily and one briefly exploring Bebo. All the girls at School 1 used MSN chat - they described being 'always connected' when online for any reason with MSN chat running in the background. But though there were still over half using chat regularly for up to 2-3 hours in the other schools, boarding school restricted use at school 2 while 3 
students at the rural school did not use it at all. Males, particularly, described gaming as addictive and discussed the way their time could be wasted online and was something they were attempting to minimise as they reached their final years of school. Students at the rurally based location seemed particularly committed to using their time for schoolwork and outside activities.

By grade 11 this group had many experiences of antisocial behaviour on the Internet to recount (see summary Table 5). These were similar to the those described by the grade 8 and 9 group: the spreading of rumours, circulation of personal emails, embarrassing people deliberately circulating photos and even posting videos to YouTube. Several girls spoke of being approached on chat by strangers who, because they had friends with them at the time, they continued chat "for fun", even though the chat included sexually explicit comments from an older man. They said if they were on their own they blocked such approaches as it was scary. They had also experienced identity theft and reported as invasion of privacy when people copied and pasted online chat into messages they then sent on to others who'd been under discussion - not something you can do with spoken gossip.

By grade 11 students were mainly self-reliant, and used a variety of cybersafety strategies. They realised that if you laughed about an embarrassing photo when it was first seen, friends didn't perceive it as an infringement of your privacy when they forwarded it to another friend. They talked of how codes of privacy should be discussed at school. They were becoming aware of how written text without body language was hard to interpret and could easily be misinterpreted. They thought that instead of answering by text in such situations they should ask the person their intent first.

Attitudes to parental/school support varied but mostly the older students felt it was unnecessary to involve them, unless there were exceptional circumstances. Technical solutions were helpful such as a new system (at School 2) of email shutting down quickly if a computer was not being used. This avoided incidents where others could have sat at their computer and written a damaging email in their name as their computer was open.

Suggestions for strategies varied from better education of parents/teachers so that they don't acquire only negative impressions of social networking, to better support systems at school (including a code of conduct for communication) though they saw this as something for people who needed support such as younger students rather than for 11th

Table 5

Summary of negative cyber experiences of Grades 11 (16-17 years)

\begin{tabular}{|c|c|c|}
\hline School 1: city-girls only & $\begin{array}{l}\text { School 2: regional co-ed } \\
\text { boarding school }\end{array}$ & School 3: rural co-ed \\
\hline $\begin{array}{l}\text { Spreading rumours, making } \\
\text { things up }\end{array}$ & $\begin{array}{l}\text { Sexual advances when flirting } \\
\text { "for fun" with unknown people }\end{array}$ & Unpleasant photos posted \\
\hline Picking on people & ‘stolen’ identity & Abusive emails \\
\hline $\begin{array}{l}\text { Hacking-people pretending to be } \\
\text { you }\end{array}$ & Images posted without permission & $\begin{array}{l}\text { Mischief involving passwords and } \\
\text { stolen identity }\end{array}$ \\
\hline $\begin{array}{l}\text { Circulation of other peoples' } \\
\text { comments using copy/paste }\end{array}$ & & (mainly reported of others) \\
\hline
\end{tabular}


graders. They agreed that they had a responsibility to the younger members of the school to advise them and discuss their experiences and help them provide strategies to counter cyberbullying.

\section{Comparative School and Regional Data}

Students of all ages enjoyed the positive capabilities of the Internet and mobile phones and were involved in texting, games, music, browsing the Internet, social networking and chat. Interest in social networking was at its greatest with the year 8-9 age group. Younger students preferred to play games and older students used person-to-person communication, using email to a greater extent. All schools data seem to indicate that the high activity in middle grades (grades 8-9) in exploring connectivity via the Internet and social networking sites, particularly MySpace, with the use of text messaging also particularly high, subsides by the time they get to senior level of studies (grade 11) and were more committed to spending time on study. Students at School 1, the city based all girls' school were particularly negative about seeking assistance from their parents and teachers, whereas the students at School 2, the boarding school, had a more trusting relationship with their teachers. The students from School 3 were not online as much as the others: a rural location perhaps gave them more time to be involved outside actively in a closer community.

\section{Discussion}

As other studies have found (Kowalski and Limber, 2007), students in grades 8 and 9 were most active in communicating electronically and most likely to have experienced cyberbullying and able to describe several incidents of this behaviour. This age group have reached a stage of constant and confident usage of electronic and internet connection at an age recognised as a confrontational phase of adolescence, often resulting in their being separated into special programs and separate campuses. This age-related conflict is now being translated into the cyberworld with students 'fighting' mainly on MySpace and through MSN chat or by mobile phone text messaging. The popularity of social networking sites in the last few years has provided a new place for such incidents to occur when previously email and mobile phones were the main sources of such harassment (Smith et al., 2006; Campbell, 2005; Li, 2005). This study found that females in this age group were more likely to use nasty postings or messages to hurt other girls known to them. The capacity on MySpace for ranking of 'friends,' as well as enabling group discussions on sites, set up tension between the 'cool' group and those they called the 'loser' group - all reflecting the playground tensions of the past but now shared out of school hours and often with a wider distribution and more hurtfully in the written word. Circulation of embarrassing photos and videos was considered something that had to be laughed off at this age though they considered them quite offensive and worrying. Most studies have identified girls as users of such forms of covert bullying (Wolak et al., 2007; Blair (2003) in (Campbell, 2005)), though Li (2006) found that boys claimed a 
higher incidence of bullying both in person and electronically. As survey data, Li can only interpret this difference though it may be because bullying is seen as a more acceptable male behaviour to claim, or, as Kowalski and Limber (2007) suggest, some girls may be unaware that their behaviour can be described as bullying particularly when they are not faced with the sight of the victim's response. The students in these focus groups had all been educated about cybersafety and showed an awareness of what constituted cyberbullying. There was a higher rate of reports about cyberbullying by girls but, unlike other studies, they were not being asked to report their roles as bullies or victims.

Despite their cybersafety education, this 13-15 year age group were threatened by online strangers in several ways. Some discussed following up external stranger contacts via, chat or email even though they were aware of the dangers this behaviour could pose. These contacts resulted in explicit sexual approaches and some students described setting up meetings with strangers, arranging these in public places to screen whether these contacts fit their online descriptions (some turned out to be older men) but potentially putting themselves at risk. They described incidents of their personal details being hacked through online connection leading to criminal activity taking money using internet bank details. False or stolen identity was a problem both with outsiders and people the students knew who could read private emails and send out defamatory messages using a person's name. Playing online games seemed to be an area that many (mainly males) in this age group knew well and they also discussed incidents of strangers becoming threatening and verbally abusive online if they lost a game.

The youngest students were genuinely disturbed about intimidating messages threats from 'outside' which frightened them and at this age were only just beginning to use technology for social exclusion and harassment of some students. Older students in the study were not especially threatened by cyberbullying. They were used to the tricks such as those involving stolen passwords to social networking sites, sending of fraudulent emails, and did not get too upset: they seemed confident of dealing with strangers online.

It was evident that the younger the student, the greater the need for support. There were two kinds of support discussed: practical help about how to get rid of harassers, offensive material etc., and moral support. Younger students were willing to talk with everyone about their problems but 13-15 year olds prefer not to go any further than their friendship group for support and were particularly wary of involving adults, as found in other studies (Campbell, 2005; Kowalski and Limber, 2007) in case adults restricted their use of communication technologies. Senior students in this study seemed to be selfreliant though considered parents and teachers important in really worrying situations. Wolak's et al. (2007) definition of cyberbullying requiring adult intervention would not be an applicable definition with this sample as they avoided adult intervention in any but the most extreme incidents. Ways of coping with cyber-bullying ranged from ignoring the offender to going up to the offender (when they are known) in person to confront them. There was an awareness from a young age that a written message could hurt much more than a spoken one and by grade 11 many had learned strategies of not writing a negative message before trying to sort out issues face to face rather than online which was much more damaging. This type of behaviour, if shared between peer groups, could provide a way of preventing and coping with cyberbullying. 
In suggesting cybersafety strategies, better education about the Internet was widely favoured for parents and teachers as much as for students themselves. This was, apparently, to reduce alarmist responses by 'elders' to new situations, which they did not fully understand. A code of conduct for better communication amongst students had some support but introducing rules and bans at school was viewed critically and as a challenge to defy. Support from IT people would suit most students (e.g., tracing harassers, blocking unwanted messages). There were no clear differences between age groups in suggesting strategies, except that the older students saw a need or responsibility to assist younger students: equally, younger students saw senior students as their best resource in dealing with cyber-bullying. This mutual regard for each other could be a basis for ongoing cybersafety strategies.

\section{Conclusions}

The cyberworld with which Australian school students are coping has changed with the widespread use of social networking sites, particularly MySpace, and the use of chat (instant messaging) through sites such as MSN Chat. These new landscapes provide places for cyberbullying through hurtful and defamatory messages, social exclusion and ranking of friends as well as threats of stolen identities and passwords that enabled bullies to send out harmful messages using others' identities and thereby causing them social harm. Email and mobile phone usage are still used for harassment and bullying and, though the students in this study had been well educated about cybersafety and cyberbullying, they were still trying to devise the best responses to these situations.

Students of all ages in the study were online, connected by computers that were often used in isolated environments away from adult supervision. They were all involved in games, music, texting, browsing the Internet, social networking and chat. Interest in social networking was at its greatest with the grade 8-9 age group. Younger students preferred to play games and older students used person-to-person communication, using email, to a greater extent. All schools' data seem to indicate that the high activity in early teens (grade 8) in exploring connectivity via the Internet, and with the use of text messaging particularly high, subsides by the time they get to senior level of studies (grade 11).

The youngest students were intimidated by threatening messages such as chain email and sought technical (and adult) help to control such experiences. Grades 8 and 9 were the age group most affected by cyberbullying and external threats to their cybersafety and personal safety if they responded through risky behaviours. This age group were most unwilling to involve teachers and parents in the difficulties they faced online, often because they feared loss of access and privileges with their communication technologies or because they were concerned that adults would not handle the issues effectively and would make the problem with their peers worse. The older students showed an encouraging maturity with their use of the internet in particular, Some had learned to distrust electronic communication for its possible misinterpretation and resulting confrontation and preferred to handle issues in person if possible. They were beginning to understand 
that they had a responsibility to help younger students and such strategies of peer mediation or mentoring and counselling by older students was seen as an acceptable approach by many students of all age groups.

Students' support of wider education of adults, particularly parents, about their cyberworld and how to manage it effectively as well as such education for students, and their support of a peer mediation and counselling strategy could be used in effectively managing schools' responses, particularly to cyberbullying. School restrictions of usage of mobile phones, email, chat sites and social networking can provide some protection from cyberbullying but as much of this usage occurs outside of school hours, the virtual playground now accompanies the student home and such restrictions only delay the potential for cyberbullying. More parental supervision of computer and phone use in open family areas could provide some support should students suffer cyberbullying, but the reality of students' need for online research for study purposes often limits computer use to quieter, less distracting spaces. Open communication by students with unjudgemental parents and teachers about the enjoyment of electronic connection to friends, with demonstration of their social networking sites and chat skills, may mean adults will be more willingly approached if they are threatened by cybersafety issues. However, peers and older students who have been designated in mediating roles and earned respect as trustworthy and knowledgeable about the cyberworld, can provide contacts for counselling which are acceptable to students of all ages as they struggle to manage cyberbullying and cybersafety threats.

\section{Acknowledgements}

This study was made possible through a partnership with the Association of Independent Schools of Victoria, particularly with support from Dr. Gerard Calnin and Dr. Paul Weldon. Dr. Karin Barty provided invaluable help organising and analysing the research data. Their help with the research is gratefully acknowledged.

\section{References}

Bamford, A. (2004). Cyberbullying. Paper presented at AHISA Pastoral Care National Conference, Melbourne, September 2004.

Campbell, M. (2005). Cyberbullying: an old problem in a new guise? Australian Journal of Guidance and Counselling, 15(1), 68-76.

Carr-Gregg, M. (2007). Real Wired Child. What Parents Need to Know about Kids Online. Penguin, Camberwell.

Kowalski, R.M. and Limber, S.P. (2007). Electronic bullying among middle school students. Journal of Adolescent Health, 41(6, Supplement 1), S22-S30.

$\mathrm{Li}$, Q. (2007). Bullying in the new playground: Research into cyberbullying and cyber victimisation. Australasian Journal of Educational Technology, 23(4), 435-454.

Li, Q. (2006). Cyberbullying in schools: A research of gender differences. School Pyschology International, 27(2), 157-170.

Li, Q. (2005). New bottle but old wine: a research of cyberbullying in schools. Computers in Human Behaviour, 23(4), 1777-1791. 
Patchin, J. and Hinduja, S. (2006). Bullies move beyond the schoolyard. Youth Violence and Juvenile Justice, $4(2), 148-169$.

Smith, P., Mahdavi, J., Carvalho, M. and Tippett, N. (2006). An investigation into cyberbullying, its forms, awareness and impact, and the relationship between age and gender in cyberbullying. Report to the AntiBullying Alliance.

http:antibullyingalliance.org.uk/downloads/pdf/cyberbullyingreportfinal. $230106.000 . p d f$

Steves, V. (2005). Young Canadians in a Wired World: Phase 11, Trends and Recommendations. Media Awareness Network, Ottawa.

Stys, Y. (2004). Beyond the schoolyard: examining electronic bullying among Canadian youth. Unpublished Masters Thesis, Carleton University, Ottawa.

http://www.bullying.org/bullyingdev/client_files/text_documents/Final $\because 20$ M.A. $\% 20$ Thesis.doc

Wolak, J., Mitchell, K. and Finkelhor, D. (2007). Does online harassment constitute bullying? An exploration of online harassment by known peers and online-only contacts. Journal of Adolescent Health, 41, S51-S58.

E. Stacey is an associate professor at Deakin University, Melbourne, Australia. She has researched and supervised researchers as well as taught about topics covering a range of interactive communication technologies including online learning via the Internet, computer conferencing, collaborative learning in a virtual environment, interactive television and audiographics through blended, open and distance education. 


\section{Elektroninio priekabiavimo tyrimas: mokiniu perspektyvos naudotis saugiomis mokymosi aplinkomis}

\section{Elizabeth STACEY}

Šiame straipsnyje nagrinejjami kokybinio tyrimo, skirto elektroninio saugumo ir elektroniniu priekabiavimu sunkumams atskleisti, rezultatai. Aptariami būdai, kaip mokiniai ịveikia ar bando ivveikti šios rǔšies problemas. Atliekant tyrimą dalyvavo 74 mokiniai (10-17 metu amžiaus) iš triju Viktorijos mokyklu (Australija), kurie buvo suskirstyti pagal amžiu ị tris grupes. Elektroninio priekabiavimu dažniausia pasitaikè viešose svetainèse ir sinchroniniuose susirašinejjimo tinklalapiuose, priekabiavimo atveju buvo ir susirašinejjant el. paštu bei siunčiant trumpasias žinutes. Elektroninio priekabiavimo ir neleistino elgesio internete bei elektroninės erdvės saugumo pažeidimų daugiausia padaro 8 ir 9 klasės mokiniai. Nustatyta, kad daugelis grupių labiau linkę patys arba pasitarę su draugais įveikti šiuos sunkumus, nei kreiptis pagalbos ị tèvus ar mokytojus, kurie gali apriboti ju prieigą prie interneto. Mokiniai vis tik pritaria, kad su šiomis problemomis turi būti supažindinami ir suaugusieji, ir mokiniai. Taip pat jie pritaria, kad jų bendraamžiai, nukentejję nuo elektroninio priekabiavimo, būtų konsultuojami. 